\title{
The Effect of PMII Strategy Towards RRT in Concept Mastery and Students Critical Thinking Ability
}

\author{
Ariesta Wulandari Ciptaningtyas* \\ Teknik Elektro \\ Sekolah Tinggi Teknik Malang \\ Malang, Indonesia \\ *ariestawulandari88@gmail.com
}

\author{
Akhmad Sidiq \\ Teknik Arsitektur \\ Sekolah Tinggi Teknik Malang \\ Malang, Indonesia \\ akhmad4javier@gmail.com
}

\author{
Chandra Sundaygara \\ Fakultas Sains dan Teknologi \\ Universitas PGRI Kanjuruhan Malang \\ Malang, Indonesia \\ chandrakirana@unikama.ac.id
}

\begin{abstract}
The aims of this research is to know the effect of reverse role tutoring (RRT) peer mediated instruction and intervention (PMII) strategy on the collage students 'conceptual mastery and students' critical thinking skills. The research method used a Quasi-experimental research design using a posttest only control groups design. The subjects of this study were 60 students from the fifth semester majoring in electrical engineering, that were selected using purposive sampling technique. The research instrument was a matter of conceptual mastery and about critical thinking skills. Data analysis using $T$ test. The results of data analysis show that there are differences in concept mastery and critical thinking skills in the experimental class and the control class. The t-test of concept mastery shows $t$ count $>t$ table $(4.906>2.000)$, and $t$-test of critical thinking ability $t$ count $>t$ table $(3.486>2.000)$. The results of this study indicate that there is a significant effect of the reverse role tutoring (RRT) type of peer mediated instruction and intervention (PMII) strategy on students' mastery of concepts and critical thinking skills.
\end{abstract}

Keywords-Peer Mediated Instruction and Intervention (PMII), Reverse Role Tutoring (RRT), concept mastery, critical thinking ability

\section{INTRODUCTION}

The learning process that can activate students is a learning process that is interactive, collaborative, and student-centered [1]. One of the interactive, collaborative, and student-centered learning models is peer-mediated instruction and intervention (PMII) reverse role tutoring (RRT) [2]. Based on the results of observations in the field, it states that the learning carried out refers to the teacher center or focuses on the lecturers. It can be seen that most of the students do not understand the concept of the courses being taught. The application of peer tutor learning to students has not been done so often in the field. Therefore, this study wants to apply the PMII type RRT learning strategy to students.

PMII has been proven to be effective in improving learning outcomes [3-5]. In addition, PMII is also able to increase metacognitive awareness and academic abilities [6,7]. The PMII meta-analysis conducted by Johnson [7] reported that more than 900 social studies were found and interdependent.

Mastery of concepts is a person's ability to understand what is being taught, capture the meaning of what is learned, utilize the content of the material being studied, and solve problems related to the material being studied. Inquiry learning strategies and peer tutors in mathematic learning are able to develop selfefficacy and mastery of concepts from the students [8].

One of the skills that expected to be an output in the ongoing learning process is critical thinking skills $[9,10]$. In line with learning in the 21 st century which requires students to have competencies in the form of problem solving, communicative, collaborative and critical thinking skills [11]. Critical thinking processes to solve problems can be trained by giving problems about complex cognitive activities [12]. Ability to think critically has a very high increase in the application of peer tutor learning in mathematics learning [13].

\section{METHODS}

The design used in this study was a quasi-experimental, the research design used a post-test only control group design. Learning using 2 groups, namely the experimental group and 
the control group. Based on table 1 the experimental group is the group that using the Peer Mediated Instruction and Intervention (PMII) learning strategy of the Reverse Role Tutoring (RRT) type, while the control group is the group that uses conventional learning, namely the Teacher Center.

TABLE I. EXPERIMENT DESIGN

\begin{tabular}{|c|c|c|c|}
\hline \multirow{2}{*}{ Groups } & Treatment & \multicolumn{2}{|c|}{ Post - Treatment } \\
\cline { 3 - 4 } & & $\boldsymbol{P B}$ & $\boldsymbol{K B} \boldsymbol{K}$ \\
\hline Experiment & $\mathrm{X}$ & $\checkmark$ & $\checkmark$ \\
\hline
\end{tabular}

\begin{tabular}{|l|l|l|l|}
\hline Control & - & $\checkmark$ & $\checkmark$ \\
\hline
\end{tabular}

\section{RESULTS AND DISCUSSION}

\section{A. Concept Mastery Data}

The following is the T-Test results of concept mastery data presented in table 2 .

TABLE II. T-TEST CONCEPT MASTERY

\begin{tabular}{|c|c|c|c|c|c|c|c|c|c|c|}
\hline \multicolumn{11}{|c|}{ Independent Samples Test } \\
\hline & & \multicolumn{2}{|c|}{$\begin{array}{c}\text { Levene's Test for } \\
\text { Equality of Variances }\end{array}$} & \multicolumn{7}{|c|}{ t-test for Equality of Means } \\
\hline & & \multirow[t]{2}{*}{$F$} & \multirow[t]{2}{*}{ Sig. } & \multirow[t]{2}{*}{$t$} & \multirow[t]{2}{*}{$d f$} & \multirow[t]{2}{*}{ Sig. (2-tailed) } & \multirow[t]{2}{*}{$\begin{array}{c}\text { Mean } \\
\text { Difference }\end{array}$} & \multirow[t]{2}{*}{$\begin{array}{l}\text { Std. Error } \\
\text { Difference }\end{array}$} & \multicolumn{2}{|c|}{$\begin{array}{l}95 \% \text { Confidence Interval } \\
\text { of the Difference }\end{array}$} \\
\hline & & & & & & & & & Lower & Upper \\
\hline \multirow[t]{2}{*}{ KBK } & $\begin{array}{l}\text { Equal variances } \\
\text { assumed }\end{array}$ & 2.113 & .151 & 3.486 & 58 & .001 & 4.167 & 1.195 & 1.774 & 6.559 \\
\hline & $\begin{array}{l}\text { Equal variances } \\
\text { not assumed }\end{array}$ & & & 3.486 & 53.443 & .001 & 4.167 & 1.195 & 1.770 & 6.563 \\
\hline
\end{tabular}

Based on the results of the T test, the concept mastery data shows that the significance value, which is 0.000 <compared to the significance level of 0.05 with the t table value of 4.906> the $\mathrm{t}$ value of 2,000 , so it can be concluded that there is a significant difference in the concept mastery data between the experimental class and the control class. The effect of concept mastery on the results of this study also supports the results of previous studies which state that peer tutoe learning can improve students' mastery of concepts [8].

\section{B. Critical Thinking Ability Data}

The Following T-Test results data on critical thinking skills are presented in table 3 .

TABLE III. T-TEST FOR CRITICAL THINKING ABILITY

\begin{tabular}{|c|c|c|c|c|c|c|c|c|c|c|}
\hline \multicolumn{11}{|c|}{ Independent Samples Test } \\
\hline & & \multicolumn{2}{|c|}{$\begin{array}{c}\text { Levene's Test for } \\
\text { Equality of Variances }\end{array}$} & \multicolumn{7}{|c|}{ t-test for Equality of Means } \\
\hline & & \multirow[t]{2}{*}{$F$} & \multirow[t]{2}{*}{ Sig. } & \multirow[t]{2}{*}{$t$} & \multirow[t]{2}{*}{$d f$} & \multirow[t]{2}{*}{ Sig. (2-tailed) } & \multirow[t]{2}{*}{$\begin{array}{c}\text { Mean } \\
\text { Difference }\end{array}$} & \multirow[t]{2}{*}{$\begin{array}{l}\text { Std. Error } \\
\text { Difference }\end{array}$} & \multicolumn{2}{|c|}{$\begin{array}{c}95 \% \text { Confidence Intervat } \\
\text { of the Difference }\end{array}$} \\
\hline & & & & & & & & & Lower & Upper \\
\hline KBK & $\begin{array}{l}\text { Equal variances } \\
\text { assumed }\end{array}$ & 2.113 & .151 & 3.486 & 58 & .001 & 4.167 & 1.195 & 1.774 & 6.559 \\
\hline & $\begin{array}{l}\text { Equal variances } \\
\text { not assumed }\end{array}$ & & & 3.486 & 53.443 & .001 & 4.167 & 1.195 & 1.770 & 6.563 \\
\hline
\end{tabular}

Based on the results of the $\mathrm{T}$ test, the critical thinking ability data shows that the significance value is 0.001 <compared to the significance level of 0.05 with a $\mathrm{T}$ table value of 3.486> the $T$ value of 2,000 , so it can be concluded that there is a significant difference in the critical thinking ability data between the experimental class and the control class.

The influence of critical thinking skills on the results of this study also supports the results of previous studies which state that peer tutoring or PMII type RRT can improve students' critical thinking skills. The critical thinking process to solve problems can be trained by giving problems [12]. About complex cognitive activities. The ability to think critically has a very high increase in the application of peer tutoring learning [13].

\section{CONCLUSION}

In this study, it can be concluded that the RRT type PMII learning strategy can improve students' mastery of concepts and critical thinking skills.

\section{REFERENCES}

[1] Kemenristekdikti, "Standar Nasional Pendidikan Tinggi," Prod. Huk., no. 49, pp. 21-23, 2014, [Online]. Retrieved from: http://www.kopertis12.or.id/wpcontent/uploads/2014/06/permen_tahun2014_nomor049.pdf.

[2] T. Hall and A. Stegila, "Peer-Mediated Instruction/Intervention NCAC Classroom Practices Peer-Mediated Instruction and Intervention," pp. 119, 2003. 
[3] N.W. Mahendrayani, "Pengaruh Model PMII Tipe CWPT Berbantuan Mnemonic terhadap hasil belajar IPA Siswa Kelas V SD,” J. Mimb. PGSD Univ. Ganesa, vol. 2, no. 1, 2014.

[4] A. Kurnianti, I. Ismail, and S. Mania, "Perbandingan Penerapan Model pembelajaran Peer Mediated Instruction and Intervention dan Model Pembelajaran Think Pair-Share," Jurnal Biotek, vol. 4, pp. 278-296, 2016.

[5] A. Arif, "Perbandingan Penerapan Model Pembelajaran Peer Mediated Instruction and Intervention dan Model Pembelajaran Think Pair Share," bionature, vol. 17, no. 2, pp. 125-133, 2017.

[6] Y. Yursal, M. Muhibbuddin, and S. Samingan, "Pengaruh Penerapan Pembelajaran Peer Mediated Instruction and Intervention (Pmii) Tipe Class-Wide Peer Tutoring (Cwpt) Terhadap Peningkatan Kesadaran Metakognitif Pada Konsep Ekosistem Di Sma Negeri 1 Paya Bakong," J. Edubio Trop., vol. 4, no. 2, pp. 24-35, 2016

[7] H. Hamsiah, "Peer-Mediated Instruction and Intervention (PMII)," Encycl. Spec. Educ., vol. 1, no. September, pp. 274-283, 2014.

[8] D. Yulianto, "Pengaruh Strategi Pembelajaran Inkuiri Dan Tutor Sebaya Terhadap Self Efficacy Dan Penguasaan Konsep Matematis," Pasundan
Journal of Mathematics Education Jurnal Pendidikan Matematika, vol. 10 , no. 1 , pp. $25-38,2020$

[9] Kemendikbud, "Permendikbud No. 21 Tahun 2016 - Standar Is Pendidikan Dasar dan Menengah," 2016

[10] E.R. Lai, "Critical thinking: A literature review," Pearson's Research Reports, vol. 6, pp. 40-41, 2011

[11] E.D. Nasihah, S. Supeno, and A.D. Lesmono, "Pengaruh Tutor Sebaya Dalam Pembelajaran Problem Based Learning Terhadap Keterampilan Berpikir Kritis Fisika Siswa Sma,” J. Pendidik. Fis., vol. 8, no. 1, p. 44, 2020.

[12] M.P. Rahayu, S. Supeno, and S.H.B. Prastowo, "Kemampuan Menyelesaikan ILL Structured Problem Siswa SMApada Pembelajaran Fisika Materi Hukum Newton," Semin. Nas. Pendidik. Fis. 2018, vol. 3, no. 2, pp. 40-44, 2018.

[13] A. Amir, "Penerapan Metode Tutor Sebaya Untuk Meningkatkan Keterampilan Berfikir Kritis Siswa Dalam Pembelajaran Matematika (Studi Kasus Di Kelas XI MIA-3 MAN Sipirok Tapanuli Selatan),' Logaritma J. Ilmu-ilmu Pendidik. dan Sains, vol. 7, no. 01, pp. 41, 2019. 